\title{
FAKTOR-FAKTOR YANG MEMPENGARUHI KEPATUHAN WAJIB \\ PAJAK USAHA MIKRO KECIL DAN MENENGAH (UMKM) \\ DALAM MEMBAYAR PAJAK SESUAI PP No.46 TAHUN 2013 PADA UMKM DI KABUPATEN BANTUL
}

\author{
Ready Wicaksono, S.E.,M.Ak.,Ak \\ Sekolah Tinggi Ilmu Ekonomi Balikpapan
}

\begin{abstract}
ABSTRAK
Pada pertengahan Juli tahun 2013 pemerintah merilis peraturan pemerintah yang mengatur perlakuan khusus pajak penghasilan untuk usaha kecil, mikro dan menengah. Peraturan pemerintah tersebut adalah peraturan pemerintah Nomor 46 tahun 2013. Peraturan ini diadakan untuk mempermudah mereka sehingga para wajib pajak dalam membayar pajak. peraturan ini mempermudah mereka sehingga para wajib pajak tidak perlu menghitung laba mereka, pajak yang harus dibayar langsung dikalikan 1\% dari omset saja. Usaha Kecil dan Menengah mempunyai peranan yang cukup besar dalam perekonomian Indonesia, namun dalam pengembangan usahanya masih menemui hambatan seperti ketidakpastian pasar, keberlangsungan usahanya dan pembukuan yang tidak jelas. Kesadaran wajib pajak, Pengetahuan dan pemahaman wajib pajak terhadap PP No.46 tahun 2013 diharapkan dapat meningkatkan kepatuhan wajib pajak dalam membayar pajak sedangkan sanksi denda dimaksudkan agar masyarakat patuh dan mau melunasi kewajiban pajaknya, serta kualitas pelayanan fiskus juga dapat mendorong kepatuhan dalam membayar pajaknya. Tujuan dari penelitian ini adalh untuk mengetahui gambaran pelaku UMKM tentang kesadaran wajib pajak, pengetahuan dan pemahaman terhadap PP No.46 tahun 2013, sanksi denda, serta kualitas pelayanan fiskus. Obyek penelitian meliputi Pelaku UMKM di Kabupaten Bantul. Pemilihan sampel responden menggunakan metode purposive sampling. Hasil dari penelitian ini menunjukkan bahwa pelaku UMKM di kabupaten Bantul memiliki kesadaran, pengetahuan dan pemahaman yang cukup tentang PP No 46, sanksi denda dalam perpajakan serta kualitas pelayanan fiskus yang dirasa cukup baik. Key words : UMKM, PP No.46 Tahun 2013 Kepatuhan Pajak.
\end{abstract}




\section{PENDAHULUAN}

\section{Latar Belakang Masalah}

Pajak adalah salah satu tumpuan utama bagi pemerintah yang digunakan untuk membiayai segala pengeluaran yang bersifat rutin maupun pengeluaran untuk pembangunan. Di pertengahan tahun 2013 Pemerintah Republik Indonesia Menerbitkan peraturan terbaru tentang perpajakan yang tertuang dalam PP No. 46 tahun 2013. Sebuah peraturan yang mengatur tentang pajak penghasilan atas penghasilan dari usaha yang diterima atau diperoleh wajib pajak yang memiliki peredaran bruto tertentu. PP No. 46 tahun 2013 terbit dilandasi oleh adanya potensi pajak dari sektor Usaha Mikro Kecil dan Menengah (UMKM) yang belum tergali secara optimal.

Walaupun tidak secara tegas dikatakan dalam PP No. 46 tahun 2013, tidak dapat dipungkiri lagi bahwa yang menjadi sasaran dalam peraturan perpajakan terbaru ini adalah Usaha Mikro Kecil dan Menengah (Tambunan, 2013). Hal ini sangat jelas terlihat dari batasan peredaran usaha $\mathrm{Rp} \mathrm{4,8} \mathrm{miliar} \mathrm{dalam}$ PP tersebut yang senyatanya masih dalam koridor pengertian UMKM sesuai dengan Undang-Undang No. 20 tahun 2008 yaitu tentang Usaha Mikro, Kecil dan Menengah, yaitu suatu usaha yang dilakukan oleh orang pribadi atau badan usaha dengan peredaran maksimal $\mathrm{Rp} 50$ miliar dalam setahun.

Wacana untuk menjadikan sektor UMKM menjadi fokus atau sasaran perpajakan telah terdengar sejak pertengahan tahun 2011. Pada tahun 2009 kelompok usaha ini telah terbukti mampu memberikan kontribusi yang signifikan terhadap pembentukkan Produk Domestik Bruto (PDB) nasional dan ekspor. Kontribusinya secara total dalam PDB sebesar 55,6\%, mampu menyerap tenaga kerja sebanyak $96,18 \%$ dengan nilai investasi 52,9\%, dan kinerja ekspor non migas mencapai 20,2\% (Kementerian Negara Koperasi dan Usaha Mikro Kecil dan Menengah 2009). Selain itu berdasarkan data statistik 2010 dalam situs Kementerian Koperasi dan UKM, jumlah UMKM di Indonesia jauh lebih besar dibandingkan usaha besar (1: 11.125). Tidak hanya itu, 57,12\% Product Domestik Bruto (PDB) dan $97 \%$ penyerapan tenaga kerja nasional merupakan kontribusi UMKM. Tahun 2011 kontribusi dalam PDB sebesar 57,94\%. Oleh sebab itu besar kemungkinan jika terbitnya PP 46 tahun 2013 tersebut ialah akibat potensi penerimaan pajak dari sektor UMKM belum tergali secara optimal.

Usaha ekstensifikasi dan intensifikasi pajak merupakan aksi yang telah dicanangkan oleh Dierktorat Jenderal Pajak dalam rangka meningkatkan penerimaan pajak, yaitu dengan memperluas subyek dan obyek pajak atau dengan menjaring wajib pajak baru. Di lain pihak perkembangan usaha-usaha kecil dan menengah yang demikian dinamis barangkali jauh meninggalkan jangkauan pajak. meskipun jaring pengamanan bagi wajib pajak berupa (Nomor Pokok Wajib Pajak) agar melaksanakan kewajiban perpajakannya sudah dipasang, terutama bagi usaha-usaha kecil menengah tersebut, tetapi masih tetap ditemukan usaha-usaha kecil 
menengah yang lepas dari jeratan pajak.

Dengan diberlakukannya PP No.46 tahun 2013, yaitu pengenaan tarif final $1 \%$ dari peredaran bruto diharapkan penerimaan sektor pajak dari Wajib Pajak UMKM dapat ditingkatkan. Selain itu memberikan kemudahan bagi Wajib Pajak UMKM yang selama ini kesulitan dalam melakukan pembukuan. Sebelum berlakunya PP No. 46, Indonesia menerapkan model standard regime dengan kemudahan dan fasilitas tertentu. Kemudahan diberikan kepada Wajib Pajak Orang Pribadi (WP OP), sebagaimana diatur dalam pasal 14 ayat (2) UU PPh, yaitu WP OP yang melakukan kegiatan usaha atau pekerjaan bebas yang peredaran brutonya dalam satu tahun kurang dari Rp 4,8 miliar, diperkenankan menggunakan Norma Penghitungan Penghasilan Neto (NPPN) dalam penghitungan penghasilan kena pajaknya sedangkan reduced rate diberlakukan untuk wajib pajak badan, sebagaimana diatur dalam pasal 31E UU PPh, bahwa WP Badan dalam negeri dengan peredaran bruto dalam satu tahun sampai dengan $\mathrm{Rp}$ 50 miliar, mendapat fasilitas berupa pengurangan tarif sebesar $50 \%$ dari tarif normal $\mathrm{PPh}$ yang dikenakan atas penghasilan kena pajak dari bagian peredaran bruto sampai dengan Rp 4,8 miliar. Penyempurnaan tersebut berjalan dengan arah dan tujuan pembangunan nasional serta kebijakan pemerintah dalam pembangunan jangka panjang (PJP) Tahap II yang antara lain bunyinya "Sistem perpajakan terus disempurnakan, pemungutan pajak diintensifkan, dan aparat kepajakan harus semakin mampu dan bersih". (Mardiasmo,2000)

Pajak bagi wajib pajak, baik perseorangan maupun Badan Usaha seringkali dirasakan sebagai beban. Oleh sebab itu peran dan partisipasi seluruh masyarakat Indonesia tanpa memandang dari golongan manapun sangat dibutuhkan demi kelancaran reformasi perpajakan. Titik berat dalam keberhasilan reformasi perpajakan adalah menumbuhkan tingkat kesadaran masyarakat sebagai wajib pajak untuk melakukan perwujudan pengabdian dan peran serta wajib pajak untuk secara langsung dan bersama-sama melaksanakan kewajiban perpajakan, bertanggung jawab atas kewajiban pelaksanaan pajak Nasional.

Menurut Dinas Perindustrian dagang dan koperasi kabupaten Bantul (Disperidagkop) penghasilan yang didapat oleh para pelaku usaha mikro kecil dan menengah yang berada di kabupaten bantul tidak selalu sama sehingga dengan adanya pemberlakukan dari pemerintah yaitu dengan diterbitkannya PP NO 46 yang berlaku efektif tahun 2013 kemarin dirasa memberatkan oleh pelaku usaha mikro kecil menengah di Kabupaten Bantul. Pemberlakuan pajak bagi UMKM per 1 Juli 2013, dianggap berpotensi mematikan ribuan usaha mikro kecil dan menengah (UMKM) karena masih banyak UMKM yang belum mapan yang terbebani dengan pajak semacam itu. Terlebih lagi dengan adanya sanksi denda yang mulai berlaku per 1 januari 2014 atas keterlambatan membayar pajak sebesar 2\% menambah beban bagi pelaku usaha yang berada Untuk itu peneliti tertarik melakukan penelitian 
mengenai faktor-faktor yang mempengaruhi kepatuhan masyarakat khususnya dari sudut pandang pelaku usaha UMKM terhadap peraturan perpajakan yaitu PP No 46 tahun 2013 yang berlaku efektif per 1 Juli 2013.

\section{Rumusan Masalah Penelitian}

Apakah kesadaran Wajib Pajak, pengetahuan dan pemahaman, sanksi denda, dan pelayanan fiskus berpengaruh positif terhadap kepatuhan membayar pajak sesuai PP No. 46 tahun 2013?

\section{KAJIAN PUSTAKA}

Teori Kepatuhan Pajak

Pendekatan teoritis utama kepatuhan pajak pada umumnya dibagi ke dalam pendekatan 'pencegahan ekonomi', dan pendektan perilaku yang lebih luas yang mencakup kedua pendekatan psikologis sosial dan fiskal.

\section{Model Pencegahan Ekonomi}

Model yang telah didasarkan pada teori kepatuhan ekonomi pada umumnya berfokus pada pencegahan. Pencegahan dapat dicapai melalui sejumlah pendekatan, hukuman dan persuasive. Artinya, pencegahan dapat mengambil bentuk meningkatkan kemungkinan deteksi, meningkatkan tarif pajak atau pengenaan penalties yang ketat. Atau, mungkin mengambil bentuk pendidikan yang lebih baik, peningkatan iklan/publisitas dan insentif.

Studi pada 1960an prinsip model pencegahan ekonomi karya Becker, yang menganalisis perilaku illegal yang menggunakan kerangka ekonomi. Becker mengusulkan argument yang menyiratkan bahwa pencegahn seperti probabilitas deteksi dan denda dan sanksi, berada dalam kontrol masyarakat. Becker memang mengakui, bagaimanapun, bahwa ada titik dimana penegakan menjadi tidak ekonomis dan menghasilkan kehilangan sosial. jadi, bahkan pada tahap sangat awal penelitian kepatuhan ini, ada pengakuan bahwa model pencegahan ekonomi murni memiliki keterbatasan.

Setelah model Becker, allingham dan Sandmo menurunkan sebuah model didasarkan pada sejumlah asumsi termasuk pembayar pajak sebagai pemaksimal utilitas yang memiliki pengetahuan yang sebenarnya dari tingkat dan deteksi penalty. Menurutnya individu memeiliki "anugerah" pendapatan yang tetap (I) dan harus melaporkan pendapatannya ke pemerintah untuk menentukan besarnya pajak yang harus dibayarkannya. Notasi D merupakan declared income, yaitu tingkat pendapatan wajib pajak yang sedia untuk dilaporkan tidak dikenai pajak, tetapi sebagai konsekuensinya individu akan dimungkinkan untuk diaudit dengan probabilitas $\mathrm{p}$ dengan denda/sanksi sebesar $f$ yang harus dibayar untuk setiap pendapatan yang tidak dikenakan pajak. individu akan memilih D untuk memaksimalkan utilitas yang diharapkannya dari tindakan coba-cobanya.

\section{Fiskal dan Model Psikologi Sosial}

Model psikologi fiskal

berbaur bersama-sama aspek model pencegahan ekonomi dan model psikologi sosial. Dorongan penting dari pendekatan ini adalah bahwa individu bukan hanya memaksimalkan utilitas semata tapi merupakan individu yang diakui mengandung berbagai sikap dan 
keyakinan yang berinteraksi dan menanggapi norma-norma sosial. Model psikologi sosial induktif memeriksa sikap dan keyakinan dari pembayar pajak untuk memahami dan memprediksi perilaku manusia.

\section{Pemahaman tentang Kepatuhan Wajib Pajak}

Menurut Nurmantu (2003), kepatuhan perpajakan didefinisikan sebagai "suatu keadaan dimana wajib pajak memenuhi semua kewajiban perpajakan dan melaksanakan hak perpajakannya". Terdapat dua macam kepatuhan menurut Nurmantu (2003), yakni: kepatuhan formal dan kepatuhan material. Kepatuhan formal adalah suatu keadaan dimana wajib pajak memenuhi kewajiban perpajakan secara formal sesuai dengan ketentuan dalam undangundang perpajakan. Kepatuhan material yaitu suatu keadaan dimana wajib pajak secara substantif atau hakikat memenuhi semua ketentuan material perpajakan. Wajib pajak yang memenuhi kepatuhan material adalah wajib pajak yang mengisi dengan jujur, lengkap, dan benar Surat Pemberitahuan (SPT) sesuai ketentuan dan menyampaikannya ke KPP sebelum batas waktu berakhir.

\section{Kesadaran Membayar Pajak}

Menurut Widayati dan Nurlis (2010) kesadaran merupakan unsur dalam manusia dalam memahami realitas dan bagaimana cara bertindak atau menyikapi terhadap realitas. Kesadaran yang dimiliki oleh manusia kesadaran dalam diri, akan diri sesama, masa silam, dan kemungkinan masa depannya.

Menurut Suyatmin (2004), kesadaran adalah keadaan mengetahui atau mengerti, sedangkan perpajakan adalah perihal pajak. Penilaian positif masyarakat wajib pajak terhadap pelaksanaan fungsi negara oleh pemerintah akan menggerakkan masyarakat untuk mematuhi kewajibannya untuk membayar pajak.

\section{Pengetahuan dan Pemahaman terhadap PP 46 tahun 2013 \\ Menurut Widayati dan Nurlis} (2010), pengetahuan adalah hasil kerja fikir (penalaran) yang merubah tidak tahu menjadi tahu dan menghilangkan keraguan terhadap suatu perkara.

Ada beberapa pokok-pokok penting bahwa wajib pajak mengetahui dan memahami peraturan pemerintah No 46 tahun 2013. Pertama, bagi wajib pajak badan tidak termasuk bentuk usaha tetap yang menerima penghasilan dari usaha dengan peredaran bruto tidak melebihi Rp 4,8 miliar dalam satu tahun pajak, dikenakan pajak penghasilan yang bersifat final dengan tarif $1 \%$. Kedua, dasar pengenaan pajak yang digunakan untuk menghitung pajak penghasilan final adalah jumlah peredaran bruto setiap bulan. Ketiga, dikecualikan dari pengenaan $\mathrm{PPh}$ final berdasarkan ketentuan ini adalah penghasilan dari jasa sehubungan dengan pekerjaan bebas yang diperoleh; tenaga ahli, pemain musik, olahragawan, penasihat, pengarang, agen iklan, pengawas atau pengelola proyek, perantara. Keempat, tidak termasuk dalam pengertian wajib pajak yang dikenakan dengan PP ini adalah wajib pajak orang pribadi yang melakukan kegiatan usaha perdagangan dan / atau jasa yang dalam usahanya 
menggunakan sarana atau prasarana yang dapat dibongkar pasang, baik yang menetap maupun tidak menetap dan menggunakan sebagian atau seluruh tempat untuk kepentingan umum yang tidak diperuntukkan bagi tempat usaha atau berjualan. Kelima, PP ini tidak berlaku atas penghasilan yang bersifat final berdasarkan ketentuan perpajakan yang berlaku.

\section{Sanksi Denda}

Sanksi adalah hukuman negatif kepada orang yang melanggar peraturan, dan denda adalah hukuman dengan cara membayar uang karena melanggar peraturan dan hukum yang berlaku, sehingga dapat dikatakan bahwa sanksi denda adalah hukuman negatif kepada orang yang melanggar peraturan dengan cara membayar uang (Jatmiko, 2006).

Menurut Jatmiko (2006), Undang-undang dan peraturan secara garis besar berisikan hak dan kewajiban, tindakan yang diperkenankan dan tidak diperkenankan oleh masyarakat. Agar Undang-undang dan peraturan itu dipatuhi, maka harus ada sanksi bagi pelanggarnya, demikian halnya untuk hukum pajak (Suyatmin, 2004). Saefudin (2003) mengemukakan bahwa Undang-undang pajak dan peraturan pelaksanaannya tidak memuat jenis penghargaan bagi WP yang taat dalam melaksanakan kewajiban perpajakan baik berupa prioritas untuk mendapatkan pelayanan publik ataupun piagam penghargaan. Walaupun WP tidak mendapatkan penghargaan atas kepatuhannya dalam melaksanakan kewajiban perpajakan, WP akan dikenakan banyak hukuman apabila alfa atau sengaja tidak melaksanakan kewajiban perpajakannya.

\section{Kualitas Pelayanan Fiskus}

Menurut Tjiptono (2007), kualitas pelayanan merupakan suatau kondisi dinamis yang berpengaruh dengan produk, jasa, manusia, proses dan lingkungan yang memenuhi atau melebihi harapan. Pelayanan adalah suatu kegiatan atau urutan kegiatan yang terjadi dalam interaksi langsung antara seseorang dengan orang lain atau mesin secara fisik, dan menyediakan kepuasan pelanggan.

$$
\text { Menurut Jatmiko (2006) }
$$

pelayanan adalah cara melayani (membantu mengurus dan menyiapkan segala keperluan yang dibutuhkan seseorang). Sementara itu fiskus adalah petugas pajak. sehingga pelayanan fiskus dapat diartikan sebagai cara petugas pajak dalam membantu mengurus atau menyiapkan segala keperluan yang dibutuhkan seseorang (dalam hal ini Wajib Pajak).

\section{Penelitian Terdahulu}

Widayati dan Nurlis (2010) Dalam hasil penelitiannya dapat disimpulkan bahwa Faktor Kesadaran membayar pajak mempunyai pengaruh yang tidak signifikan terhadap kemauan wajib pajak untuk membayar pajak. sedangkan faktor pengetahuan dan pemahaman tentang peraturan pajak mempunyai pengaruh signifikan terhadap kemauan wajib pajak untuk membayar pajak.

Jatmiko (2006) Dalam

Penelitiannya dapat disimpulkan bahwa Faktor Sikap Wajib Pajak terhadap Sanksi Denda, Sikap Wajib Pajak terhadap Pelayanan Fiskus, dan Sikap Wajib Pajak terhadap 
Kesadaran Perpajakan berpengaruh posistif terhadap kepatuhan membayar pajak.

\section{Hipotesis Penelitian}

Kesadaran Membayar Pajak berpengaruh Positif terhadap Kepatuhan Wajib Pajak UMKM

Menurut Widayati dan Nurlis (2010), kesadaran merupakan unsur dalam manusia dalam memahami realitas dan bagaimana cara bertindak atau menyikapi terhadap realitas. Kesadaran yang dimiliki oleh manusia kesadaran dalam diri, akan diri sesama, masa silam, dan kemungkinan masa depannya.

Munculnya peraturan terbaru pemerintah tentang pajak penghasilan atas penghasilan dari usaha yang diterima atau diperoleh wajib pajak yang memiliki peredaran bruto tertentu yaitu PP No. 46 Tahun 2013 di landasi oleh adanya potensi pajak dari sektor UMKM yang belum tergali secara optimal. Kesadaran pelaku UMKM atas perpajakan amatlah diperlukan guna meningkatkan kepatuhan, sehingga ketika WP sudah semakin sadar akan kewajibannya untuk membayar pajak maka dia akan semakin patuh untuk membayar pajak. Berdasarkan hal tersebut maka dirumuskan hipotesis sebagai berikut:

(H1): Kesadaran WP UMKM untuk membayar pajak berpengaruh positif terhadap kepatuhan membayar pajak sesuai dengan PP 46 tahun 2013.

Pengetahuan dan Pemahaman tentang PP No. 46 berpengaruh Positif terhadap Kepatuhan Wajib Pajak UMKM

Menurut Widayati dan Nurlis (2010), pengetahuan adalah hasil kerja fikir (penalaran) yang merubah tidak tahu menjadi tahu dan menghilangkan keraguan terhadap suatu perkara. Pengetahuan adalah informasi yang diketahui atau disadari oleh seseorang. Dalam pengertian lain, pengetahuan adalah berbagai gejala yang ditemui dan diperoleh manusia melalui pengamatan akal. Pengetahuan muncul ketika seseorang menggunakan akal budinya untuk mengenali benda atau kejadian tertentu yang belum pernah dilihat atau dirasakan sebelumnya (Utami dkk., 2012).

Faktor lain yang mempengaruhi kepatuhan wajib pajak dalam membayar pajak sesuai dengan PP No. 46 ini ialah Keikutsertaan Wajib Pajak dalam mengikuti sosialisasi yang dilakukan oleh KPP. Wajib pajak yang tidak memahami peraturan perpajakan secara jelas cenderung akan menjadi wajib pajak yang tidak taat. Jelas bahwa semakin paham wajib pajak terhadap peraturan perpajakan, maka semakin paham pula wajib pajak terhadap sanksi yang akan diterima bila melalaikan kewajiban perpajakan mereka. Setiap wajib pajak yang telah memahami peraturan perpajakan sangat baik, biasanya akan melakukan aturan perpajakan yang ada sesuai dengan apa yang tercantum di dalam peraturan yang ada.

(H2) : Pengetahuan dan
pemahaman WP UMKM
tentang PP 46 berpengaruh
positif terhadap kepatuhan
membayar pajak sesuai
dengan PP 46 tahun 2013




\section{Sanksi Denda berpengaruh Positif terhadap Kepatuhan Wajib Pajak UMKM}

Sanksi adalah hukuman negatif kepada orang yang melanggar peraturan, dan denda adalah hukuman dengan cara membayar uang karena melanggar peraturan dan hukum yang berlaku, sehingga dapat dikatakan bahwa sanksi denda adalah hukuman negatif kepada orang yang melanggar peraturan dengan cara membayar uang (Jatmiko, 2006).

Saefudin

mengemukakan bahwa undangundang pajak dan peraturan pelaksanaannya tidak memuat jenis penghargaan bagi WP yang taat dalam melaksanakan kewajiban perpajakan baik berupa prioritas untuk mendapatkan pelayanan publik ataupun piagam penghargaan. Walaupun WP tidak mendapatkan penghargaan atas kepatuhannya dalam melaksanakan kewajiban perpajakan, WP akan dikenakan banyak hukuman apabila alfa atau sengaja tidak melaksanakan kewajiban perpajaknnya.

Menurut Jatmiko (2006) WP akan mematuhi pembayaran pajak bila memandang sanksi denda akan lebih banyak merugikannya. Semakin banyak sisa tunggakan pajak yang harus dibayar WP, maka akan semakin berat bagi WP untuk melunasinya. Oleh sebab itu sikap atau pandangan WP terhadap sanksi denda diduga akan berpengaruh terhadap tingkat kepatuhan WP dalam membayar pajak. hal ini sangat relevan jika digunakan sebagai variabel bebas dalam penelitian ini:

(H3) : Sanksi denda berpengaruh positif terhadap kepatuhan WP dalam membayar pajak sesuai dengan PP No. 46 Tahun 2013.

\section{Kualitas Pelayanan Fiskus Berpengaruh Positif Terhadap Kepatuhan Wajib Pajak UMKM}

Kualitas pelayanan fiskus terhadap wajib pajak menjadi suatu hal yang penting dalam kesadaran wajib pajak untuk mau membayar pajak. Oleh sebab itu meningkatkan kualitas pelayanan fiskus terhadap wajib pajak menjadi hal utama. Terlebih bagi para pelaku UMKM yang merasa kurang mengerti alasan pemerintah mengenakan tarif final $1 \%$ setelah munculnya peraturan terbaru yaitu PP No. 46 tahun 2013 yang berlaku efektif 1 Juli 2013.

Kepatuhan wajib pajak dalam memenuhi kewajibannya membayar pajak tergantung pada bagaimana petugas pajak memberikan mutu pelayanan yang terbaik kepada wajib pajak. Selama ini peranan yang fiskus miliki lebih banyak pada peran seorang pemeriksa. Padahal untuk menjaga agar wajib pajak tetap patuh terhadap kewajiban perpajakannya dibutuhkan peran yang lebih dari sekedar pemeriksa Panggabean (2002). Sehingga ketika fiskus mampu memberikan pelayanan yang baik maka WP akan semakin patuh untuk membayarkan pajaknya.

(H4) : Kualitas pelayanan fiskus berpengaruh positif terhadap kepatuhan WP dalam membayar pajak sesuai dengan PP No. 46 Tahun 2013.

\section{Metode Penelitian \\ Jenis Penelitian}

Ditinjau dari metode pengambilan datanya, maka penelitian ini merupakan penelitian 
survei. Survei atau lengkapnya selfadministered survey adalah metode pengumpulan data primer dengan memberikan pertanyaan-pertanyaan kepada responden individu (Hartono, 2014).

\section{Populasi dan Sampel}

Dalam penelitian ini populasi terdiri dari seluruh wajib pajak perseorangan maupun badan UMKM di Kabupaten Bantul. Jumlah pelaku UMKM di Kabupaten Bantul berjumlah 18.199 (Disperindagkop, 2014).

Sampel penelitian adalah bagian dari jumlah dan karakteristik yang dimiliki oleh populasi tersebut. Metode pengambilan sampel yang digunakan dalam penelitian ini adalah pengambilan sampel berbasis pada Nonprobabilitas (pemilihan nonrandom), yaitu Purposive Sampling, pengambilan (purposive sampling) dilakukan dengan mengambil sampel dari populasi berdasarkan suatu kriteria tertentu (Hartono, 2014).

\section{Skala Pengukuran}

Tipe dasar dari skala pengukuran yang digunakan dalam penelitian ini adalah skala interval.

\section{Definisi dan Pengukuran Variabel Variabel dependen}

Variabel dependen dalam penelitian ini adalah Tingkat Kepatuhan Wajib Pajak UMKM sesuai PP 46 (Y). Nurmantu (2003), kepatuhan perpajakan didefinisikan sebagai "suatu keadaan dimana wajib pajak memenuhi semua kewajiban perpajakan dan melaksanakan hak perpajakannya".

\section{Variabel Independen}

a. Kesadaran membayar pajak (X1) Kesadaran adalah kondisi dimana seorang individu memiliki kendali penuh terhadap stimulus internal maupun stimulus eksternal dengan kata lain kesadaran adalah keadaan seseorang mengetahui atau mengerti, sedangkan perpajakan adalah perihal pajak. sehingga kesadaran perpajakan adalah keadaan mengetahui atau mengerti perihal pajak.

b. Pengetahuan dan pemahaman tentang PP 46

Pengetahuan adalah hasil kerja fikir (penalaran) yang merubah tidak tahu menjadi tahu dan menghilangkan keraguan terhadap suatu perkara.

c. Sanksi Denda

Sanksi Denda menurut Devano dan Rahayu dalam buku perpajakan konsep, teori dan isu adalah sanksi administrasi yang dikenakan terhadap pelanggaran yang berkaitan dengan kewajiban pelaporan.

d. Pelayanan Fiskus

Menurut Tjiptono (2007), kualitas pelayanan merupakan suatau kondisi dinamis yang berpengaruh dengan produk, jasa, manusia, proses dan lingkungan yang memenuhi atau melebihi harapan.

\section{Uji Kualitas Data \\ Uji Validitas}

Validitas menunjukkan seberapa nyata suatu pengujian mengukur apa yang seharusnya diukur (Hartono, 2014). Pengukuran dikatakan valid jika mengukur tujuannya dengan nyata atau benar. 
Uji Reliabilitas

Reliabilitas menunjukkan akurasi dan ketepatan dari pengukurnya yang berhubungan dengan konsistensi dari pengukur (Hartono, 2014). Suatu pengukur dikatakan reliabel (dapat diandalkan) jika dapat dipercaya, akurat, dan konsisten.

\section{Metode Analisis Data \\ Uji asumsi Klasik \\ Uji Multikolinieritas}

Uji multikolinieritas untuk menguji apakah model regresi ditemukan adanya korelasi antar variabel independent. Model regresi yang baik adalah tidak terdapat korelasi diantara variabel independent.

\section{Uji Heterokedastisitas}

Uji Heterokedastisitas bertujuan untuk menguji apakah data model regresi terjadi ketidaksamaan variance dari residual satu pengamatan ke pengamatan yang lain, jika terdapat perbedaan maka disebut heterokedastisitas, sedangkan model regresi yang baik adalah homokedastisitas (tidak terjadi heterokedastisitas).

\section{Uji Normalitas}

Uji normalitas bertujuan untuk menguji apakah dalam model regresi, variabel dependen dan variabel independen keduanya mempunyai distribusi normal atau tidak. Model regresi yang baik adalah yang terdistribusi normal atau mendekati normal.

\section{Uji hipotesis}

Untuk menguji hipotesis digunakan analisis regresi linear berganda. Rumusnya adalah sebagai berikut:

$\mathrm{Y}=\mathrm{a}+\beta \mathrm{X}_{1}+\beta \mathrm{X}_{2}+\beta \mathrm{X}_{3}+\beta \mathrm{X}_{4}+\mathrm{e}$
Keterangan:

$\mathrm{Y}=$ Tingkat Kepatuhan UMKM Terhadap pp 46

$\mathrm{a}=$ Konstanta

$\beta X=$ Koefisien Regresi

$\mathrm{X}_{1}=$ Variabel kesadaran membayar pajak

$\mathrm{X}_{2}=$ Variabel Pengetahuan dan Pemahaman PP 46

$\mathrm{X}_{3}=$ Variabel Sanksi Denda

$\mathrm{X}_{4}=$ Variabel Kualitas Pelayanan Fiskus

$\mathrm{e}=$ Error term, nilai kesalahan observasi disamakan nol

Adapun kriteria pengujian hipotesis adalah Ho ditolak jika sig $\mathrm{t}$ $<\alpha(0,05)$ dan tanda koefisien regresi bernilai positif seperti yang diprediksi.

\section{Analisis Data Dan Pembahasan} Hasil Pengumpulan Data

Responden yang diambil untuk penelitian ini sebanyak 110 responden baik untuk responden wajib pajak UMKM yang berbentuk badan maupun perorangan. Teknik pengumpulan data dilakukan dengan cara mengantarkan langsung kepada responden yang sudah ditentukan sebelumnya. Dari rencana kuesioner yang disebar kepada responden sebanyak 110 kuesioner, hanya 100 kuesioner yang memenuhi syarat untuk dianalisis baik untuk.

\section{Uji Validitas dan Reliabilitas Uji Validitas}

Pengujian validitas data yaitu melakukan uji korelasi antara skor masing-masing butir dengan skor total (pearson corelation).

Dari hasil perhitungan pearson correlation di atas, seluruh item pernyataan mempunyai nilai signifkansi kurang dari 0,05 , yang artinya seluruh item pernyataan dan 
pertanyaan pada variabel penelitian dinyatakan valid, sehingga item pernyataan tersebut dapat dinyatakan layak sebagai instrumen untuk mengukur data penelitian.

\section{Uji Reliabilitas}

Reliabilitas adalah sejauh mana hasil suatu pengukuran dapat dipercaya dan dapat memberikan hasil yang relatif tidak berbeda apabila dilakukan kembali kepada subyek yang sama. Dari hasil uji reliabilitas diperoleh seluruh variabel penelitian ini dapat dinyatakan reliabel karena koefisien alpha lebih besar dari 0,6, maka dapat disimpulkan bahwa Item-Item pernyataan dan pertanyaan dapat digunakan sebagai instrumen untuk penelitian selanjutnya.

\section{Uji Asumsi Klasik}

\section{Heteroskedastisitas}

Pengujian heteroskedastisitas dapat dilakukan dengan menggunakan grafik scatterplots, jika grafik terlihat titik-titik menyebar secara acak dan tersebar di atas maupun dibawah angka 0 sumbu $\mathrm{Y}$ maka tidak terjadi heteroskedastistas pada model regresi. Hasil uji heteroskedastisitas dapat dilihat pada Gambar 4.1 di bawah ini :

\section{Gambar 4.1}

\section{Hasil Uji Heteroskedastisitas}

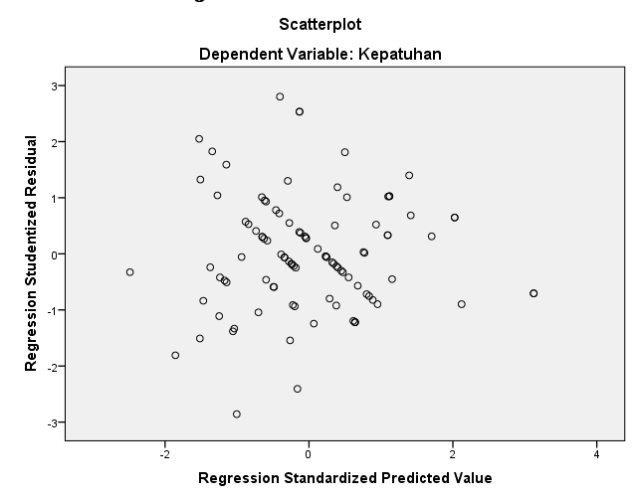

Sumber : Data Diolah, 2015
Dari hasil analisis uji heteroskedastisitas di atas, pada grafik scatterplot terlihat titik-titik menyebar secara acak dan tersebar di atas maupun dibawah angka 0 sumbu Y. Hasil tersebut dapat disimpulkan bahwa tidak terdapat gejala heteroskedastisitas dalam model regresi dan dapat digunakan untuk analisis selanjutnya.

\section{Multikolinieritas}

Multikolinearitas dapat dideteksi pada model regresi apabila variabel terdapat pasangan variabel bebas yang saling berkorelasi kuat satu sama lain. Untuk mengetahui ada atau tidaknya multikolinieritas maka dapat dilihat dari nilai Varians Inflation Factor (VIF). Bila angka VIF ada yang melebihi 10 berarti terjadinya multikolinieritas.

\section{Hasil Uji Multikolinieritas}

\begin{tabular}{|c|c|c|c|}
\hline \multicolumn{4}{|c|}{ Coefficients $^{\mathrm{a}}$} \\
\hline \multirow{2}{*}{\multicolumn{2}{|c|}{ Model }} & \multicolumn{2}{|c|}{ Collinearity Statistics } \\
\hline & & Tolerance & VIF \\
\hline \multirow{5}{*}{1} & Kesadaran & .629 & 1.590 \\
\hline & Pengetahua & .842 & 1.188 \\
\hline & & & \\
\hline & Sanksi & .610 & 1.639 \\
\hline & $\begin{array}{l}\text { Kualitas } \\
\text { pelayanan }\end{array}$ & .722 & 1.385 \\
\hline
\end{tabular}

a. Dependent Variable: Kepatuhan

Sumber : Data Diolah, 2015

Dari hasil perhitungan diperoleh bahwa pada bagian collinierity statistic, nilai VIF pada seluruh variabel independen lebih kecil dari 10 dan nilai tolerance di atas 0.1 . Hasil tersebut dapat diartikan bahwa seluruh variabel independen pada penelitian ini tidak ada gejala multikolinieritas.

\section{Uji Normalitas}

Uji normalitas bertujuan untuk menguji apakah dalam model regresi, variabel tergantung dan 
variabel bebas keduanya mempunyai distribusi normal atau tidak.

\section{Hasil Uji Normalitas}

One-Sample Kolmogorov-Smirnov Test

\begin{tabular}{|ll|r|}
\hline \multicolumn{2}{|c|}{ One-Sample Kolmogorov-Smirnov Test } & $\begin{array}{c}\text { Unstandardi } \\
\text { zed } \\
\text { Residual }\end{array}$ \\
\hline $\mathrm{N}$ & Mean & 100 \\
Normal Parameters & & .0000000 \\
& Std. & .35642839 \\
& Deviation & .058 \\
Most Extreme Differences & Absolute & .058 \\
& Positive & -.040 \\
Kolmogorov-Smirnov Z & Negative & .576 \\
Asymp. Sig. (2-tailed) & & .894 \\
\hline a. Test distribution is Normal. & \\
b. Calculated from data. &
\end{tabular}

Dari hasil uji kolmogorovsmirnov di atas, dihasilkan nilai Asymp. Sig. (2-tailed) sebesar 0,894. Hasil tersebut dapat disimpulkan bahwa data residual dalam model regresi ini terdistribusi normal karena nilai Asymp. Sig. (2-tailed) di atas 0,05 dan model regresi tersebut layak digunakan untuk analisis selanjutnya.

\section{Analisis Regresi Linier Berganda}

Analisis ini digunakan untuk mengetahui besarnya pengaruh variabel independen terhadap variabel dependen.

\section{Hasil Analisis Regresi Linier Berganda}

\begin{tabular}{|c|c|c|c|}
\hline \multirow{2}{*}{\multicolumn{2}{|c|}{ Model }} & $\begin{array}{c}\text { Unstandardi } \\
\text { zed } \\
\text { Coefficients } \\
\end{array}$ & \multirow[t]{2}{*}{ Sig. } \\
\hline & & $\mathrm{B}$ & \\
\hline \multirow{5}{*}{1} & (Constant) & .362 & .125 \\
\hline & Kesadaran & .181 & .033 \\
\hline & Pengetahuan & .189 & .002 \\
\hline & Sanksi & .466 & .000 \\
\hline & $\begin{array}{l}\text { Kualitas } \\
\text { pelayanan }\end{array}$ & .134 & .021 \\
\hline
\end{tabular}

Sumber : Data Diolah, 2015

Berdasarkan tabel diatas, maka model regresi yang diperoleh adalah sebagai berikut :

$\mathrm{Y}=0,362+0,181 \mathrm{KSDR}+$ 0,189PENG + $0,466 S A N K S I+0,134 K P+e$

Adapun hasil pengujian hipotesis dalam penelitian ini adalah sebagai berikut :

1. Pengujian Hipotesis Pertama

Pengujian terhadap hipotesis ini dilakukan melalui pengujian signifikansi koefisien regresi dari variabel kesadaran wajib pajak. Hipotesis pertama penelitian ini menyatakan kesadaran wajib pajak berpengaruh positif terhadap kepatuhan wajib pajak. Dari hasil analisis data diatas, dihasilkan nilai koofisien regresi sebesar 0,181 dan nilai signifikansi sebesar 0,033 . Pada tingkat signifikansi $\alpha=5 \%$; maka koefisien regresi tersebut signifikan karena $0,033<0,05$ sehingga dapat disimpulkan bahwa kesadaran wajib pajak berpengaruh positif signifikan terhadap kepatuhan wajib pajak.sehingga hipotesis pertama penelitian ini diterima.

2. Pengujian Hipotesis Kedua

Pengujian terhadap hipotesis ini dilakukan melalui pengujian 
signifikansi koefisien regresi dari variabel pengetahuan wajib pajak. Hipotesis kedua penelitian ini menyatakan pengetahuan wajib pajak berpengaruh positif terhadap kepatuhan wajib pajak. Dari hasil analisis data diatas, dihasilkan nilai koofisien regresi sebesar 0,189 dan nilai signifikansi sebesar 0,002 . Pada tingkat signifikansi $\alpha=5 \%$; maka koefisien regresi tersebut signifikan karena 0,002 $<0,05$ sehingga hasil dapat disimpulkan bahwa pengetahuan wajib pajak berpengaruh positif signifikan terhadap kepatuhan wajib pajak sehingga hipotesis kedua penelitian ini diterima.

3. Pengujian Hipotesis Ketiga

Pengujian terhadap hipotesis ini dilakukan melalui pengujian signifikansi koefisien regresi dari variabel sanksi denda. Hipotesis ketiga penelitian ini menyatakan sanksi dengan berpengaruh positif terhadap kepatuhan wajib pajak. Dari hasil analisis data diatas, dihasilkan nilai koofisien regresi sebesar 0,466 dan nilai signifikansi sebesar 0,000. Pada tingkat signifikansi $\alpha=5 \%$; maka koefisien regresi tersebut signifikan karena $0,000<0,05$ dan koofisien regresi sebesar 0,223 dapat disimpulkan bahwa sanksi pajak berpengaruh positif signifikan terhadap kepatuhan wajib pajak sehingga hipotesis ketiga penelitian ini diterima.

4. Pengujian Hipotesis Keempat Pengujian terhadap hipotesis ini dilakukan melalui pengujian signifikansi koefisien regresi dari variabel kualitas layanan. Hipotesis keempat penelitian ini menyatakan kualitas layanan berpengaruh positif terhadap kepatuhan wajib pajak. Dari hasil analisis data diatas, dihasilkan nilai koofisien regresi sebesar 0,134 dan nilai signifikansi sebesar 0,021 . Pada tingkat signifikansi $\alpha=5 \%$; maka koefisien regresi tersebut signifikan karena $0,021<0,05$ sehingga dapat disimpulkan bahwa kualitas layanan berpengaruh positif signifikan terhadap kepatuhan wajib pajak.sehingga hipotesis keempat penelitian ini diterima.

\section{Pembahasan}

Pengaruh Kesadaran Membayar Pajak Terhadap Kepatuhan Wajib Pajak UMKM

Berdasarkan hasil analisis uji hipotesis di atas, maka dapat disimpulkan bahwa kesadaran wajib pajak berpengaruh positif terhadap kepatuhan wajib pajak. Hasil ini membuktikan semakin tinggi kesadaran wajib pajak akan meningkatkan tingkat kepatuhan wajib pajak.

Hasil ini membuktikan bahwa kesadaran membayar pajak yang mendorong wajib pajak untuk membayar pajak. Kesadaran bahwa pajak merupakan bentuk partisipasi dalam menunjang pembangunan negara. Dengan menyadari hal ini, wajib pajak mau membayar pajak karena merasa tidak dirugikan dari pemungutan pajak yang dilakukan. Kesadaran bahwa penundaan pembayaran pajak dan pengurangan beban pajak sangat merugikan negara. Wajib pajak mau membayar pajak karena memahami bahwa penundaan pembayaran pajak dan pengurangan beban pajak berdampak pada kurangnya sumber daya finansial yang dapat mengakibatkan 
terhambatnya pembangunan negara. Kesadaran bahwa pajak ditetapkan dengan Undang-undang dan dapat dipaksakan. Wajib pajak akan membayar karena pembayaran pajak disadari memiliki landasan hukum yang kuat dan merupakan kewajiban mutlak setiap warga negara.

Munculnya peraturan terbaru pemerintah tentang pajak penghasilan atas penghasilan dari usaha yang diterima atau diperoleh wajib pajak yang memiliki peredaran bruto tertentu yaitu PP No. 46 Tahun 2013 di landasi oleh adanya potensi pajak dari sektor UMKM yang belum tergali secara optimal. Kesadaran pelaku UMKM atas perpajakan amatlah diperlukan guna meningkatkan kepatuhan, sehingga ketika WP sudah semakin sadar akan kewajibannya untuk membayar pajak maka dia akan semakin patuh untuk membayar pajak.

Hasil penelitian Suyatmin (2004) menunjukkan bahwa sikap wajib pajak terhadap kesadaran perpajakan berpengaruh positif terhadap kepatuhan wajib pajak. Soemarso (1998) menyatakan bahwa kesadaran perpajakan masyarakat yang rendah seringkali menjadi salah satu sebab banyaknya potensi pajak yang tidak dapat dijaring. Lerche (1980) juga mengemukakan bahwa kesadaran perpajakan seringkali menjadi kendala dalam masalah pengumpulan pajak dari masyarakat. Kesadaran wajib pajak atas perpajakan amatlah diperlukan guna meningkatkan kepatuhan wajib pajak.

Dari hasil penelitian Utami, dkk (2012) didapatkan hasil dimana kesadaran membayar pajak memiliki pengaruh positif dan signifikan dengan tingkat kepatuhan. Hasil penelitian menunjukkan bahwa adanya pengaruh kesadaran terhadap tingkat kepatuhan, hal ini dapat diartikan bahwa wajib pajak sadar dengan membayar pajak akan menjadi salah satu sumber yang digunakan untuk pembiayaan pembangunan negara. Selain itu dalam penelitian Pratiwi dan Setiawan (2014) mengemukakan bahwa kesadaran wajib pajak yang semakin tinggi akan mengakibatkan perilaku wajib pajak yang semakin patuh pada kewajiban perpajakan yang harus dibayarnya. Keinginan membayar pajak dapat meningkat apabila terdapat pandangan positif yang muncul dari wajib pajak.

Pengaruh Pengetahuan dan Pemahaman Tentang PP No. 46 Tahun 2013 Terhadap Kepatuhan Wajib Pajak UMKM

Berdasarkan hasil analisis uji hipotesis di atas, maka dapat disimpulkan bahwa pengetahuan wajib pajak berpengaruh positif signifikan terhadap kepatuhan wajib pajak. Hasil ini membuktikan semakin tinggi pengetahuan wajib pajak maka kepatuhan wajib pajak juga akan meningkat demikian pula sebaliknya.

Hasil penelitian ini membuktikan bahwa pengetahuan atau pemahaman wajib pajak atas peraturan perpajakan dapat mempengaruhi juga terhadap patuh tidaknya wajib pajak. Pengetahuan wajib pajak mengenai aturan dan ketentuan perpajakan yang berlaku diharapkan akan meningkatkan kepatuhan pajak. Informasi yang dimiliki oleh wajib pajak akan mempengaruhi mereka terhadap kepatuhan wajib pajak. Semakin 
banyak informasi yang mereka ketahui maka akan membantu mereka untuk bisa memberikan tanggapan. Namun dengan banyaknya informasi yang diperoleh dari media dapat menimbulkan yang negatif dari wajib pajak terhadap kepatuhan wajib pajak. Sedangkan wajib pajak yang kurang mendapat informasi biasanya akan biasa saja. Karena mereka tidak terlalu mengetahui duduk persoalannya maka mereka akan tetap memberikan opini positif. Pada akhirnya tingkat pengetahuan yang dimiliki oleh wajib pajak akan mempengaruhi keputusan mereka untuk memenuhi kewajiban perpajakannya.

Faktor lain yang

mempengaruhi kepatuhan wajib pajak dalam membayar pajak sesuai dengan PP No. 46 ini ialah Keikutsertaan Wajib Pajak dalam mengikuti sosialisasi yang dilakukan oleh KPP. Wajib pajak yang tidak memahami peraturan perpajakan secara jelas cenderung akan menjadi wajib pajak yang tidak taat. Jelas bahwa semakin paham wajib pajak terhadap peraturan perpajakan, maka semakin paham pula wajib pajak terhadap sanksi yang akan diterima bila melalaikan kewajiban perpajakan mereka. Setiap wajib pajak yang telah memahami peraturan perpajakan sangat baik, biasanya akan melakukan aturan perpajakan yang ada sesuai dengan apa yang tercantum di dalam peraturan yang ada.

Hasil penelitian ini sesuai Widayati dan Nurlis (2010) yang mendapatkan hasil bahwa pengetahuan wajib pajak berpengaruh positif terhadap kepatuhan wajib pajak. selain itu hasil penelitian ini kosisten dengan hasil penelitian
Utami, dkk (2012) dimana pengetahuan dan pemahaman peraturan pajak berpengaruh positif dan signifikan. Hasil penelitian ini menunjukkan bahwa pengetahuan dan pemahaman tentang peraturan perpajakan berpengaruh terhadap tingkat kepatuhan. Pada saat masyarakat mengetahui dan memahami peraturan pajak, maka masyarakatpun dapat mematuhi aturan pajak.

\section{Pengaruh Sanksi Denda Terhadap Kepatuhan Wajib Pajak UMKM}

Berdasarkan hasil analisis uji hipotesis di atas, maka dapat disimpulkan bahwa sangsi denda berpengaruh positif terhadap kepatuhan wajib pajak. Hasil ini membuktikan semakin tinggi sanksi denda wajib pajak akan meningkatkan tingkat kepatuhan wajib pajak.

Sanksi pajak dibuat dengan tujuan agar wajib pajak takut untuk melanggar Undang-undang Perpajakan. Wajib pajak akan mematuhi pembayaran pajaknya bila memandang bahwa sanksi akan lebih banyak merugikannya (Jatmiko, 2006). Sanksi pajak merupakan jaminan bahwa ketentuan peraturan perundang-undangan perpajakan (norma perpajakan) akan dituruti/ditaati/dipatuhi, dengan kata lain sanksi perpajakan merupakan alat pencegah agar wajib pajak tidak melanggar norma perpajakan Mardiasmo, 2006 . Oleh karena itu, pandangan wajib pajak mengenai sanksi perpajakan diduga akan mempengaruhi kepatuhan wajib pajak dalam membayar pajak. Menurut Jatmiko (2006) WP akan mematuhi pembayaran pajak bila memandang 
sanksi denda akan lebih banyak merugikannya. Semakin banyak sisa tunggakan pajak yang harus dibayar WP, maka akan semakin berat bagi WP untuk melunasinya. Oleh sebab itu sikap atau pandangan WP terhadap sanksi denda diduga akan berpengaruh terhadap tingkat kepatuhan WP dalam membayar pajak

Fraternesi (2001) menyatakan bahwa WP akan mematuhi pembayaran pajak bila memandang sanksi denda akan lebih banyak merugikannya. Semakin banyak sisa tunggakan pajak yang harus dibayar WP, maka akan semakin berat bagi WP untuk melunasinya. Walaupun WP tidak mendapatkan penghargaan atas kepatuhannya dalam melaksanakan kewajiban perpajakan, WP akan dikenakan banyak hukuman apabila alfa atau sengaja tidak melaksanakan kewajiban perpajakannya. Oleh sebab itu tidaklah mengherankan apabila dalam penelitian ini ditemukan semakin positif sikap wajib pajak terhadap sanksi denda maka akan semakin meningkat kepatuhan wajib pajak. temuan ini mendukung hasil penelitian Bambang Suhardito (1996), Fraternesi (2001), dan Sulud Kahono (2003) yang juga menunjukkan bahwa sikap wajib pajak terhadap sanksi denda berpengaruh positif terhadap kepatuhan pajak.

Selain itu Hasil penelitian ini juga mendukung dari hasil penelitian Pratiwi dan Setiawan (2014) juga berpengaruh positif dan signifikan pada kepatuhan wajib pajak. penerapan sanksi perpajakan kepada wajib pajak dimaksudkan agar wajib pajak tidak melalaikan kewajibannya menaati peraturan perundangundangan perpajakan. Pandangan tentang pengenaan sanksi pajak yang akan lebih merugikan apabila wajib pajak melakukan penghindaran pajak menjadi faktor pendorong bagi wajib pajak untuk memenuhi kewajiban perpajakannya sehingga salah satu cara untuk menghindari sanksi perpajakan adalah dengan melakukan pembayaran tepat waktu atau jangan melewati jangka waktu yang telah ditetapkan.

\section{Pengaruh Kualitas Pelayanan Fiskus Terhadap Terhadap Kepatuhan Wajib Pajak UMKM}

Berdasarkan hasil analisis uji hipotesis di atas, maka dapat disimpulkan bahwa kualitas layanan berpengaruh positif terhadap kepatuhan wajib pajak. Hasil ini membuktikan semakin tinggi kualitas layanan akan meningkatkan tingkat kepatuhan wajib pajak.

Kualitas pelayanan fiskus terhadap wajib pajak menjadi suatu hal yang penting dalam kesadaran wajib pajak untuk mau membayar pajak. Oleh sebab itu meningkatkan kualitas pelayanan fiskus terhadap wajib pajak menjadi hal utama. Terlebih bagi para pelaku UMKM yang merasa kurang mengerti alasan pemerintah mengenakan tarif final $1 \%$ setelah munculnya peraturan terbaru yaitu PP No. 46 tahun 2013 yang berlaku efektif 1 Juli 2013.

Fidel (2010) mengungkapkan bahwa kesan kesewenangan aparat pajak dalam melayani masyarakat maupun wajib pajak memang terlihat masih belum hilang. Kesan kesewenangan ini bisa terjadi karena banyak hal, seperti birokrasi yang masih "rumit", masih kentalnya 
perasaan sebagai Pegawai Negeri Sipil (PNS) yang merasa dilayani bukan melayani.

Kepatuhan wajib pajak dalam memenuhi kewajibannya membayar pajak tergantung pada bagaimana petugas pajak memberikan mutu pelayanan yang terbaik kepada wajib pajak. Selama ini peranan yang fiskus miliki lebih banyak pada peran seorang pemeriksa. Padahal untuk menjaga agar wajib pajak tetap patuh terhadap kewajiban perpajakannya dibutuhkan peran yang lebih dari sekedar pemeriksa Panggabean (2002).

Hasil penelitian ini konsisten dengan hasil penelitian Sulud Kahono (2003) dan Suyatmin (2004) yang juga menemukan bahwa sikap wajib pajak terhadap pelayanan fiskus berpengaruh positif terhadap kepatuhan wajib pajak. temuan ini juga mendukung pernyataan dari Miando Sahala L. Panggabean (2002) yang menyatakan bahwa kepatuhan WP dalam memenuhi kewajibannya membayar pajak tergantung pada bagaimana petugas pajak memeberikan mutu pelayanan yang terbaik kepada wajib pajak.

Hasil penelitian ini juga konsisten dengan hasil penelitian Utami, dkk (2012) yang menemukan bahwa kualitas pelayanan memiliki pengaruh positif dan signifikan dengan tingkat kepatuhan. Penelitian ini membuktikan bahwa adnya pengaruh kualitas pelayanan terhadap tingkat kepatuhan. Apabila kualitas pelayanan semakin baik maka akan cenderung meningkatkan tingkat kepatuhan wajib pajak. selain itu dalam penelitian Pratiwi dan Setiawan (2014) kualitas pelayanan juga berpengaruh positif dan signifikan yang mana mutu pelayanan terbaik yang diterima oleh wajib pajak dari petugas pajak akan membuat wajib pajak nyaman dalam membayar pajak dan meningkatkan kepatuhannya dalam membayar pajak.

\section{Penutup}

\section{Kesimpulan}

1. Berdasarkan hasil analisis uji hipotesis di atas, maka dapat disimpulkan bahwa kesadaran wajib pajak berpengaruh positif signifikan terhadap kepatuhan wajib pajak. Hasil ini membuktikan semakin tinggi kesadaran wajib pajak akan meningkatkan tingkat kepatuhan wajib pajak.

2. Berdasarkan hasil analisis uji hipotesis di atas, maka dapat disimpulkan bahwa pengetahuan wajib pajak berpengaruh positif signifikan terhadap kepatuhan wajib pajak. Hasil ini membuktikan semakin tinggi pengetahuan wajib pajak maka kepatuhan wajib pajak juga akan meningkat.

3. Berdasarkan hasil analisis uji hipotesis di atas, maka dapat disimpulkan bahwa sangsi denda berpengaruh positif signifikan terhadap kepatuhan wajib pajak. Hasil ini membuktikan semakin tinggi sanksi denda wajib pajak akan meningkatkan tingkat kepatuhan wajib pajak.

4. Berdasarkan hasil analisis uji hipotesis di atas, maka dapat disimpulkan bahwa kualitas layanan berpengaruh positif signifikan terhadap kepatuhan wajib pajak. Hasil ini membuktikan semakin tinggi 
kualitas layanan akan meningkatkan tingkat kepatuhan wajib pajak

\section{Keterbatasan Penelitian}

1. Variabel independen yang digunakan untuk mempengaruhi kepatuhan wajib pajak dalam penelitian ini hanya 4 variabel, yaitu kesadaran wajib pajak, pengetahuan wajib pajak, sanksi denda dan kualitas layanan. Dari hasil analisis koefisien determinasi, ditemukan hasil sebesar 0,569. Hasil ini dapat diartikan bahwa besarnya variabel independen dalam menjelaskan variabel dependen adalah sebesar $56,9 \%$. Sedangkan sisanya $43,1 \%$ dipengaruhi variabel lain diluar penelitian.

2. Penelitian ini hanya menggunakan populasi hanya pada wajib pajak UMKM yang berada di kabupaten Bantul saja.

\section{Saran}

1. untuk penelitian selanjutnya yang tertarik untuk melakukan kajian dibidang yang sama dapat menambahkan lagi variabelvariabel yang tidak digunakan dalam penelitian ini seperti; Faktor keadilan, tingkat penghasilan wajib pajak, adanya paksaan dari pemerintah, serta sanksi hukuman penjara. Karena Dari hasil analisis koefisien determinasi, ditemukan hasil sebesar 0,569. Hasil ini dapat diartikan bahwa besarnya variabel independen dalam menjelaskan variabel dependen adalah sebesar $56,9 \%$. Sedangkan sisanya $43,1 \%$ dipengaruhi variabel lain diluar penelitian

2. Untuk peneliti yang tertarik untuk melakukan kajian dibidang yang sama juga dapat menambahkan atau memperluas populasi tidak hanya dalam satu kabupaten Bantul saja, yaitu dapat diperluas hingga satu provinsi DIY. sehingga dapat menggeneralisasikan hasil penelitian ini.

3. Untuk penelitian selanjutnya dapat menambahkan pengumpulan datanya dengan wawancara sehingga hasil dari temuan penelitian ini dapat lebih reliabel.

4. Untuk penelitian selanjutnya pertanyaan dalam questioner harus disesuaikan dengan responden 


\section{DAFTAR PUSTAKA}

Aziza, K.S. (2013, juni 28). Penerapan Pajak UMKM, Pemerintah Klaim Ingin Bantu Usaha Kecil. Kompas.com

Budiatmanto. A. (1999). Studi Evaluasi Kepatuhan Wajib Pajak Sebelum dan Sesudah Reformasi Perpajakan Tahun 1983, Tesis Program Pasca Sarjana Magister Akuntansi Universitas Gadjah Mada Yogyakarta.

Brainyyah dan Rusydi. (2013). The Effect Of Tax Fairness, Tax Knowledge, and Tax Complexity On Tax Compliance: The Case Of SME Entrepreneurs' Taxpayers In Malang. Jurnal Ilmiah Mahasiswa FEB Universitas Brawijaya

Direktorat Jenderal Pajak, 2009. Buku Ketentuan Umum Perpajakan. http://www.pajak.go.id/content/buku-ketentuan-umum-perpajakan-2013. 10 september 2014

Devos.K (2014), Factors Influencing Individual Taxpayer Compliance Behavior, DOI 10.1007/978-94-007-7476-6_2, Springer Science+Business Media Dordrecht

Direktorat Jenderal Pajak 2013. Undang-Undang Republik Indonesia Nomor 16 Tahun 2009. Tentang Ketentuan Umum Perpajakan http://www.pajak.go.id/content/buku-ketentuan-umum-perpajakan-2013. 10 September 2014

Fidel (2010). Cara Mudah \& Praktis Memahami Masalah-Masalah Perpajakakan (Edisi 1). Jakarta, Indonesia: Murai Kencana.

Ghozali, I. (2001). Aplikasi Analisis Multivariate Dengan Program SPSS, Badan Penerbitan Universitas Diponegoro, Semarang

Undang-Undang Republik Indonesia Nomor 20 Tahun 2008. Tentang Usaha Mikro Kecil dan Menengah.

Hartono, J. (2014). Metodelogi Penelitian Bisnis: Salah Kaprah dan Pengalaman - pengalaman (Edisi 6). Yogyakarta, Indonesia: BPFE UGM.

Jatmiko, A.N. (2006). Pengaruh sikap wajib pajak pada pelaksanaan sanksi denda, pelayanan fiskus dan kesadaran perpajakan terhadap kepatuhan wajib pajak, Tesis Program Pasca Sarjana Magister Akuntansi Universitas Diponegoro Semarang.

Kahono.S. (2003), Pengaruh Sikap Wajib Pajak Terhadap Kepatuhan Wajib Pajak Dalam Pembayaran Pajak Bumi dan Bangunan: Studi Empiris di Wilayah 
KP PBB Semarang, Tesis Program Pasca Sarjana Magister Sains Akuntansi Universitas Diponegoro.

Kiryanto. (2000), Analisis Pengaruh Penerapan Struktur Pengendalian Intern Terhadap Kepatuhan Wajib Pajak badan Dalam Memenuhi Kewajiban Pajak Penghasilannya, EKOBIS, Vol. 1 No. 1, p. 41-52.

Lerche. D (1980), Efficiency of Taxation in Indonesia, BIES, Vol. 16 No. 1, p. 34 -51 .

Mardiasmo. (2009). Perpajakan (Edisi Revisi 2009). Yogyakarta, Indonesia: Andi Offset.

Novak, N.D. (1989), Tax Administrasion in Theory and Practice, Preager Publisher, London

Nurmantu, S. (2003). Pengantar Perpajakan. (Edisi 2). Jakarta, Indonesia: Granit.

Nasucha, Chaizi. (2004). Reformasi Administrasi Publik: Teori dan Praktik, Jakarta, Indonesia: PT Gramedia Widiasarana Indonesia.

Peraturan Pemerintah Republik Indonesia Nomor 46 Tahun 2013, Tentang Penghasilan Dari Usaha Yang Diterima Atau Diperoleh Wajib Pajak Yang Memiliki Peredaran Bruto Tertentu

Panggabean. (2002). Self Assessment, Fiskus dan Kepatuhan Wajib Pajak, Berita Pajak, No. 1462/Tahun XXXIV, p. $21-26$.

Pratiwi dan Setiawan. (2014). Pengaruh Kesadaran Wajib Pajak, Kualitas Pelayanan, Kondisi Keuangan Perusahaan, Dan Persepsi Tentang Sanksi Perpajakan Pada Kepatuhan Wajib Pajak Reklame Di Dinas Pendapatan Kota Denpasar. E-Jurnal Akuntasi Universitas Udayana 6.1 (2014):139135. ISSN: $2302-8556$

Rantung dan adi. (2009). Dampak Program Sunset Policy Terhadap Faktor-Faktor yang Mempengaruhi Kemauan Membayar. Makalah Simposium Nasional Perpajakan II. Madura.

Roseline dan Rusydi. (2013). Analisis Faktor-Faktor Yang Mempengaruhi Kepatuhan Wajib Pajak Dalam Mengukuhkan Diri Sebagai Pengusaha Kena Pajak. Jurnal Ilmiah Mahasiswa FEB Universitas Brawijaya.

Rajif. M. (2012). Pengaruh Pemahaman, Kualitas Pelayanan, Dan Ketegasan Sanksi Perpajakan Terhadap Kepatuhan Pajak Pengusaha UKM Di Daerah Cirebon. Publication. Gunadarma. ac. id 
Republik Indonesia 2003. Salinan Keputusan Menteri Keuangan Republik Indonesia Nomor 40/KMK.06/2003. Tentang Pendanaan Kredit Usaha Mikro Dan Kecil

Saefudin, D. (2003). Hukuman dan Penghargaan Untuk Wajib Pajak, Berita Pajak, No. 1492/Tahun XXXV, p. $24-28$.

Sulistyawati dan Poerwati. (2012). Faktor-Faktor Kemauan Membayar Pajak Wajib Pajak Orang Pribadi Yang Melakukan Pekerjaan Bebas Di KPP Semarang Barat. Student Journal Of Accounting And Banking. Unisbank

Utami, Andi, Soerono (2012). Pengaruh Faktor-faktor Eksternal Terhadap Tingkat Kepatuhan Wajib Pajak Di Lingkungan Kantor Pelayanan Pajak Pratama Serang. Simposium Nasional Akuntansi 15, Universitas Sultan Agung Tirtayasa.

Soemarso.S.R. (1998). Dampak Reformasi Perpajakan 1984 Terhadap Efisiensi Sistem Perpajakan Indonesia, "Ekonomi dan Keuangan Perpajakan di Indonesia, Vol. XLVI No.3, p. 333 - 368.

Suyatmin. (2004). Pengaruh Sikap Wajib Pajak Terhadap Kepatuhan Wajib Pajak Dalam Pembayaran Pajak Bumi dan Bangunan: Studi Empiris di Wilayah KP PBB Surakarta, Tesis Program Pasca Sarjana Magister Sains Akuntansi Universitas Diponegoro.

Susilo dan sirajudin, (2014). Pemahaman Wajib Pajak Terhadap Peraturan Pemerintah Nomor 46 Tahun 2013 Tentang Pajak UKM (Studi Kasus Pada Wajib Pajak Yang Terdaftar di Kantor Pelayanan Pajak Pratama Palembang Ilir Barat). Eprints. Mdp. ac. id

Sekaran, Uma (1992), Research Methods For Business: Skill-Buildings Approach, $2^{\text {nd }}$ Edition, Jhon Wiley \& Sons, Inc

Tambunan, R. (2013, Juli 4). Ketentuan Terbaru Pajak Penghasilan Atas UMKM: Sederhana Tapi Tidak Adil. Retrieved from http: / / www.ortax.org/?mod=issue\&page $=$ show $\& \mathrm{id}=51 \& \mathrm{q}=\& \mathrm{hlm}=1.10$ Agustus 2014.

Tjiptono. F. (2007). Manajemen Jasa, Penerbit Andi, Yogyakarta.

Widayati dan Nurlis. (2010). Faktor-Faktor Yang Mempengaruhi Kemauan Untuk Membayar Pajak Wajib Pajak Orang Pribadi Yang Melakukan Pekerjaan Bebas. Simposium Nasional Akuntansi 13, Universitas Jenderal Sudirman, Purwokerto. 